\title{
MANAJEMEN PEMBESARAN KERAPU TIKUS (Cromileptes altivelis) DI BALAI BESAR PENGEMBANGAN BUDIDAYA AIR PAYAU (BBPBAP) JEPARA JAWA TENGAH
}

\section{NURSERY MANAGEMENT OF GROUPER (Cromileptes altivelis) IN DEVELOPMENT BRACKISH WATER CENTER JEPARA CENTER JAVA}

\author{
Atmirah Septinawati dan Wahyu Tjahjaningsih
}

Fakultas Perikanan dan Kelautan Universitas Airlangga

Kampus C Mulyorejo - Surabaya, 60115 Telp. 031-5911451

\begin{abstract}
The mouse grouper is variance of grouper that have high economic value because it have high sale value so that it will increase income of aquaculturist. The right management of grouper nursery would increase production to supplied the marketing demand.

The aims of this case study were to know how nursery management of grouper and factors that influence in grouper nursery in BBPBAP Jepara, was held on 28 July until 28 August 2005. Method used were descriptive method with collection of primary data and secondary data. Data was taken by observation, interview, active participation and literature study.

Nursery of grouper fish carried out by BBPBAP Jepara under Departement of Marine and Fisheries. Source of fry were obtain from hatchery division in BBPBAP. Marine water were obtain from the sea, while fresh water were obtain from well. Fish feeding were use trash fish which were cut to suitable with mouth gapes of fish as much 90 gram, twice a day were morning and afternoon. In the fish nursery were not find disease that attack. The marketing area of grouper were Semarang, Jakarta, Surabaya, and local consumer.
\end{abstract}

Key words : grouper, Cromileptes altivelis, BBPBAP Jepara

\section{Pendahuluan}

Ikan kerapu merupakan jenis ikan yang hidup di perairan terumbu karang, yang dalam dunia internasional dikenal dengan nama grouper atau coral reef fish. Ikan kerapu juga merupakan salah satu komoditas sumberdaya perairan yang memiliki potensi besar untuk dikembangkan di Indonesia. Ikan ini memiliki nilai ekonomis yang tinggi karena rasanya yang lezat, sehingga banyak digemari terutama di mancanegara. Hal ini tentunya berpengaruh positif terhadap nilai jual di pasaran. Dewasa ini telah dikenal beberapa spesies ikan kerapu dengan nilai ekonomis yang tinggi seperti ikan kerapu tikus / bebek (Cromileptes altivelis), napoleon (Cheilinus undulatus), dan kerapu sunu (Plectropomus leoporus).

Usaha pembenihan dan pembesaran ikan kerapu di Indonesia telah mulai dikembangkan sebagai usaha alternatif dalam mengantisipasi kekurangan ikan kerapu akibat meningkatnya permintaan pasar. Namun demikian usaha ini belum dapat mencukupi kebutuhan pasar ikan kerapu yang terus meningkat tiap tahunnya. Ikan kerapu tikus (Cromileptes altivelis) merupakan salah satu jenis ikan kerapu yang mempunyai prospek pemasaran cukup baik dan harganya paling tinggi diantara jenis kerapu lainnya. Di Indonesia, ikan kerapu tikus dikenal dengan nama kerapu bebek, hal ini disebabkan ikan kerapu ini mempunyai kepala yang datar mirip kepala bebek, dan mulutnya meruncing menyerupai moncong tikus sehingga disebut juga kerapu tikus. Dalam dunia perdagangan internasional dikenal dengan nama polka-dot grouper atau hump-backed rocked. Selain itu kerapu tikus mendapat julukan panther fish, karena di sekujur tubuhnya terdapat bintik-bintik kecil berwarna hitam. Selain sebagai ikan konsumsi, kerapu tikus juga dapat dijadikan sebagai ikan hias akuarium karena mempunyai bentuk dan penampilan yang menarik, yang dikenal dengan nama grace kelly.

Permasalahan yang timbul adalah, apakah manajemen pembesaran ikan kerapu tikus yang diterapkan di BBPBAP sudah tepat serta faktor apa saja yang menghambat dalam usaha pembesaran ikan kerapu tikus di BBPBAP Jepara. 
Studi kasus ini bertujuan untuk mengetahui bagaimana manajemen pembesaran tikus di Balai Besar Pengembangan Budidaya Air Payau (BBPBAP) Jepara. Selain itu juga untuk mengetahui faktor-faktor apa saja yang mempengaruhi dalam usaha pembesaran kerapu tikus di Balai Besar Pengembangan Air Payau (BBPBAP) Jepara.

\section{Materi dan Metode Peneltian \\ Tempat dan Waktu}

Studi kasus ini dilaksanakan di Balai Besar Pengembangan Budidaya Air Payau (BBPBAP) Jepara, Desa Bulu, Kecamatan Jepara, Kabupaten Jepara, Jawa Tengah. Kegiatan ini dilaksanakan mulai tanggal 28 Juli-28 Agustus 2005.

\section{Metode Penelitian}

Metode yang digunakan dalam studi kasus ini adalah metode deskriptif. Menurut Suryabrata (1993), metode diskriptif adalah metode untuk membuat pencandraan secara sistematis, faktual dan akurat mengenai fakta-fakta dan sifat-sifat populasi atau daerah tertentu.

\section{Hasil dan Pembahasan}

Tambak pembesaran kerapu tikus dibagi menjadi beberapa petak yang disekat dengan hapa air laut dilakukan dengan memompa air laut sejauh $400 \mathrm{~m}$ dari tepi pantai dengan ukuran $1 \quad 0,5 \quad 1,5 \mathrm{~m}$. Petak tersebut digunakan untuk memelihara benih kerapu tikus yang berukuran kurang dari 3 gram, yang berasal dari divisi pembenihan.

Kincir air yang digunakan pada tambak pembesaran kerapu tikus sebanyak 2 unit. Kincir air ini berfungsi untuk meningkatkan suplai oksigen di tambak, biasanya dihidupkan pada sore hari setelah pemberian pakan sampai pagi hari sebelum pemberian pakan.

Pengambilan ditampung pada tandon air dan dilakukan penyaringan, setelah itu baru dialirkan ke bak atau tambak melalui pipa.

BBPBAP Jepara menggunakan tenaga listrik dari PLN cabang Jepara dan untuk mengantisipasi terjadinya pemadaman arus listrik, maka pada tiap unit atau divisi budidaya menggunakan generator berkekuatan 8 KVA.

Teknik pengadaan air laut dilakukan dengan cara memompa secara langsung dari laut sejauh $400 \mathrm{~m}$ dari tepi pantai dengan pompa elektromotor $20 \mathrm{PK}$, dengan menggunakan model saringan berpasir. Sistem saringan pasir tersebut terbuat dari beton berukuran panjang $5 \mathrm{~m}$, lebar $2 \mathrm{~m}$, tinggi $2 \mathrm{~m}$, dengan susunan saringan terdiri dari kerikil, ijuk, dan pasir. Ujung pipa diletakkan minimal $5 \mathrm{~m}$ dari permukaan untuk menghindari air tercemar atau air yang bersalinitas rendah karena hujan. Air tesebut setelah melewati saringan diendapkan di dalam tandon dan dihubungkan dengan pipa ke bak atau tambak yang digunakan.

Persediaan air tawar diperoleh dari sumur yang dibuat di sekitar lokasi BBPBAP Jepara dengan pompa. Air disimpan terlebih dahulu di dalam tangki penampungan (tower). Dari tower air dapat didistribusikan ke tempat yang membutuhkan.

Fungsi freezer adalah untuk menyimpan ikan rucah agar tetap segar dan tidak menurun kualitasnya. Freezer ini ditempatkan di dalam gubuk, yang dijadikan gudang atau tempat penyimpanan alat yang diperlukan.

Pembuatan shelter bertujuan sebagai tempat berlindung bagi ikan kerapu yang masih berukuran kurang dari 3 gram. Selain itu adanya shelter bertujuan pula untuk mengurangi kanibalisme. Shelter ini terbuat dari pipa PVC yang berdiameter $15 \mathrm{~cm}$ yang dipotong dan diletakkan di dasar hapa.

Alat yang digunakan antara lain, timbangan, gunting termometer serta alat untuk mengukur salinitas. Selain itu, terdapat beberapa alat yang digunakan untuk sampling yaitu timbangan digital, penggaris, seser serta wadah yang digunakan untuk menampung ikan kerapu yang akan disampling.

Kondisi jalan menuju BBPBAP Jepara cukup baik sehingga mendukung kelancaran usaha dan pendistribusian hasil produksi. Selain itu ditunjang pula dengan sarana transpotrasi yang dimiliki, meliputi 2 buah bus, 1 buah truk, 2 buah pick up, yang dipergunakan untuk berbagai keperluan BBPBAP Jepara.

Beberapa langkah yang dilakukan di BBPBAP Jepara dalam menyiapkan tambak untuk budidaya ikan kerapu tikus terdiri dari 8 tahap yaitu perbaikan konstruksi tambak, pengolahan dasar tambak, pemberantasan hama dan penyakit, pengapuran, pengisian air, penyekatan menggunakan hapa, pemantapan lingkungan serta penyediaan tempat berlindung (shelter).

Menurut SEAFDEC (2001), persiapan tambak untuk budidaya ikan kerapu tikus dibagi menjadi beberapa tahap, yaitu pengeringan, pembajakan, pembasmian predator dan kompetitor, pengapuran dan pemupukan.

Kegiatan perbaikan konstruksi tambak yang dilakukan BBPBAP Jepara adalah dengan memperbaiki pintu masuk dan pembuangan air serta 
tanggul. Tujuan perbaikan tanggul adalah agar konstruksi tanggul kuat dan tidak bocor sehingga mampu menahan jumlah air yang akan digunakan untuk budidaya. Tujuan perbaikan konstruksi adalah untuk menyiapkan kondisi tambak yang mampu menahan kedalaman air yang dikehendaki, yang dilakukan dengan perbaikan tanggul atau pematang tambak, perbaikan pintu masuk dan pembuangan air serta saluran air (www.warintek.bantul.or.id, 2006).

Kegiatan pengolahan dasar tambak yang dilakukan di BBPBAP Jepara meliputi pengeringan, penjemuran dan pengolahan tanah. Kegiatan pengeringan tambak di BBPBAP Jepara dilakukan dengan memompa air dari tambak dengan menggunakan pompa, kemudian didiamkan selama 5 hari hingga tanah kering. Tujuan pengeringan tanah tersebut adalah untuk menyiapkan tanah dasar tambak dalam keadaan kering. Selain itu, kegiatan pengeringan tanah ini bertujuan membantu membasmi binatang liar yang dapat mengganggu kelangsungan hidup ikan kerapu di tambak. Menurut Supratno dan Kasnadi (2003), pengeringan dasar tambak dimaksudkan untuk membuang limbah bahan organik yang terakumulasi di dasar tambak dan gas yang bersifat racun (toksik). Tujuan dari pengeringan adalah agar tanah dasar tambak lebih keras dan mantap. Selain itu pengeringan membantu membasmi binatang liar yang mengganggu baik sebagai predator maupun kompetitor.

Kegiatan penjemuran di BBPBAP Jepara dilakukan hingga tanah dasar kering. Waktu yang dibutuhkan untuk pengeringan tergantung cuaca dan biasanya berkisar $7-15$ hari. Tujuan penjemuran tanah tersebut adalah menyiapkan kondisi tanah dasar hingga kering dan biasanya hingga keadaan tanah retak-retak. Dengan adanya kegiatan penjemuran diharapkan kondisi tanah kering hingga dalam, tidak hanya di permukaan saja sehingga membantu proses dekomposisi tanah. Penjemuran dasar tambak dimaksudkan untuk membantu dalam proses oksidasi dan proses perombakan atau dekomposisi tanah (Komarudin, 2005).

Kegiatan pengolahan tanah dasar di BBPBAP Jepara dilakukan dengan beberapa usaha yaitu dengan membuang sisa bahan organik yang dilakukan melalui pengangkatan tanah dan lumpur, membalik tanah yang dilakukan dengan cara mencangkul sedalam $10-20 \mathrm{~cm}$. Setelah itu dilanjutkan dengan perataan dasar tambak dan diatur kemiringannya ke arah tempat pembuangan air. Tujuan pengolahan tanah dasar tersebut adalah untuk membuang sisa bahan organik yang dapat menurunkan kualitas air tambak. Kegiatan pengolahan tanah dasar ini merupakan kelanjutan dari kegiatan pengeringan dan penjemuran yang bertujuan menyiapkan kondisi tanah tambak untuk pemeliharaan kerapu tikus. Menurut Komarudin (2005), pengolahan tanah dasar tambak dimaksudkan untuk menyiapkan struktur tanah dasar yang baik dan memperbaiki struktur dan agregasi tanah.

Usaha pemberantasan hama dan penyakit yang dilakukan di BBPBAP Jepara adalah dengan menggunakan saponin. Sebelum digunakan saponin direndam dulu selama 24 jam, kemudian keesokan harinya larutan saponin tersebut disebarkan secara merata. Pemilihan penggunaan saponin karena beberapa alasan yaitu, karena saponin merupakan bahan pestisida alami yang efektif untuk membasmi ikan liar di tambak, memiliki daya racun yang tinggi dan cepat netral. Menurut Suyanto (2004), daya racun saponin terhadap ikan $50 \mathrm{x}$ lipat lebih besar daripada terhadap udang. Untuk menghilangkan bibit penyakit dan ikan liar digunakan pestisida yang dianjurkan seperti brestan-60 atau saponin dengan dosis 10 - 12 ppm (Supratno dan Kasnadi, 2003). Pemberantasan hama, penyakit dan ikan liar dimaksudkan untuk membasmi bibit penyakit dan hama atau ikan liar yang menjadi pengganggu (kompetitor atau predator), sehingga diharapkan dalam pemeliharaan tidak ada gangguan.

Kegiatan pengapuran yang dilakukan di BBPBAP Jepara menggunakan kapur pertanian dengan dosis 1,75 ton/ ha. Kapur tersebut ditaburkan ke tambak secara merata. Pengapuran dilakukan karena $\mathrm{pH}$ tanah di tambak hanya 6,5. Pengapuran dimaksudkan untuk menaikkan $\mathrm{pH}$ tanah menjadi 7,5, memperbaiki struktur tanah dan agregat tanah (Komarudin, 2005). Aplikasi pengapuran dasar tambak disesuaikan dengan kondisi tanah dan $\mathrm{pH}$ awal serta jenis kapur yang digunakan (Buwono, 1993). Jenis kapur yang dapat digunakan adalah kapur pertanian $\left(\mathrm{CaCO}_{3}\right)$, Burned line $(\mathrm{CaO})$, serta Hydrated line $\left(\mathrm{Ca}(\mathrm{OH})_{2}\right)$. Kegiatan pengapuran merupakan tindakan preventif dalam proses perbaikan alkalinitas, optimalisasi pertumbuhan dan mendapatkan kualitas air yang dikehendaki (Komarudin, 2005).

Kegiatan pengisian air di BBPBAP Jepara dilakukan secara bertahap yaitu mengisi tambak dengan air laut yang berasal dari tandon hingga ketinggian air mencapai $20 \mathrm{~cm}$, kemudian tambak diisi hingga ketinggian $1 \mathrm{~m}$. Kegiatan ini memerlukan waktu sekitar 4 - 7 hari. Pengisian air ke tambak dilakukan dari tandon untuk memenuhi media pemeliharaan ikan. Pengisian air dilakukan secara 
dengan air laut yang berasal dari tandon hingga ketinggian air mencapai $20 \mathrm{~cm}$, kemudian tambak diisi hingga ketinggian $1 \mathrm{~m}$. Kegiatan ini memerlukan waktu sekitar 4 - 7 hari. Pengisian air ke tambak dilakukan dari tandon untuk memenuhi media pemeliharaan ikan. Pengisian air dilakukan secara bertahap, artinya sedikit demi sedikit selama beberapa hari (sekitar 3 - 4 hari) hingga mencapai ketinggian 1 $\mathrm{m}$ atau lebih (SEAFDEC, 2001). Setelah itu tambak siap digunakan.

Pemberian sekat pada tambak di BBPBAP Jepara dilakukan dengan memasang hapa dengan ukuran $1 \quad 0,5 \quad 1,5 \mathrm{~m}$, dengan mengikatkan tali hapa pada bambu yang ditancapkan pada dasar tambak. Pemberian sekat dilakukan setelah pengisian air. Menurut Komarudin (2005), pemberian sekat dan hapa dilakukan dengan maksud memisahkan populasi kerapu yang berbeda ukuran agar tidak terjadi pemangsaan, terutama ikan kerapu yang masih berukuran di bawah 30 gram.

Usaha pemantapan lingkungan yang dilakukan BBPBAP Jepara adalah dengan mengukur DO, suhu, salinitas, $\mathrm{pH}$ dan amoniak yang dilakukan selama Studi Kasus. Usaha pemantapan lingkungan ini dilakukan sebelum penebaran benih yang dilakukan selama 7 hari. Pemantapan lingkungan dimaksudkan untuk mempersiapkan dan menjaga lingkungan media agar tetap stabil sehingga pada saat dilakukan penebaran benih, tidak terjadi fluktuasi yang ekstrim yang berakibat fatal pada ikan. Menurut Supratno dan Kasnadi (2003), selama pemantapan lingkungan dilakukan monitoring terhadap kualitas air (pengukuran $\mathrm{pH}, \mathrm{DO}$, suhu, salinitas, dan amoniak).

Penyediaan shelter di BBPBAP Jepara menggunakan pipa PVC dengan diameter $15 \mathrm{~cm}$ dan panjang $20 \mathrm{~cm}$. Penempatan shelter dilakukan secara meyebar di dasar hapa. Penyediaan shelter mempunyai peranan penting karena setelah ditebar ikan kerapu akan masuk ke shelter sebagai tempat untuk berlindung. Menurut Sunyoto (1994), penyediaan shelter dapat mengurangi kanibalisme atau pemangsaan dan mengurangi terjadinya serangan penyakit, sehingga dapat membantu meningkatkan sintasan atau kelangsungan hidup ikan.

Kegiatan awal sebelum benih ditebar, benih diaklimatisasi terlebih dulu. Aklimatisasi bertujuan untuk mengadaptasikan benih terhadap suhu dan salinitas agar benih tidak mengalami stres pada lingkungan pemeliharaan yang baru (Direktorat Jenderal Perikanan Budidaya, 2004). Aklimatisasi yang dilakukan oleh BBPBAP Jepara adalah dengan menampung benih dalam wadah yang telah diisi dengan air tambak selama 3 - 5 menit, kemudian aktivitas gerak benih diamati. Bila benih aktif bergerak, benih dipindahkan ke tambak yang telah di sekat dengan hapa. Selain itu, kegiatan lain yang dilakukan pada awal penebaran adalah pengambilan contoh ikan kerapu tikus untuk diukur berat dan panjang awalnya. Jumlah benih pada pengambilan contoh adalah sebanyak 10 ekor dari 200 ekor ikan kerapu. Setelah selesai dilakukan pengambilan contoh, benih dipindahkan ke tambak, yang telah diberi sekat berukuran $10,51,5 \mathrm{~m}$.

Penebaran sebaiknya dilakukan pada pagi atau sore hari untuk menghindarkan benih stres (Sunyoto, 1994). Penebaran benih yang dilakukan di BBPBAP Jepara adalah pada pagi hari yaitu sekitar jam 07.00 pagi, hal ini dilakukan agar benih tidak mengalami stres karena suhu yang tinggi.

Kegiatan pendederan di BBPBAP Jepara dilakukan selama 2 bulan di tambak yang telah dipasang hapa berukuran 1 x 1 x 1,5 m, hingga benih mencapai ukuran 30 - 50 gram dan memiliki panjang $10-12 \mathrm{~cm}$. Benih yang digunakan berasal dari divisi pembenihan, dimana benih ini berasal dari penetasan telur yang telah dipelihara selama 60 hari. Hal ini sesuai dengan pernyataan Komarudin (2005), bahwa pemeliharaan benih ikan kerapu dari mulai telur menetas dilakukan selama 2 bulan.

Padat tebar pada tambak BBPBAP Jepara adalah sebesar 200 ekor $/ \mathrm{m}^{2}$. Menurut Komarudin (2005), padat tebar pada tahap pendederan adalah $15-$ 20 ekor/m². Sedangkan menurut Sunyoto (1994), padat tebar ikan kerapu tikus ukuran 2 - 3 gram adalah sebesar 200 - 250 ekor $/ \mathrm{m}^{2}$. Berdasarkan pernyataan tersebut maka padat tebar pada tambak BBPBAP Jepara masih memenuhi syarat kelayakan bagi kehidupan kerapu tikus.

Kelulushidupan benih pada hapa pendederan selama Studi Kasus ini adalah sebesar 100\%, hal ini ditunjukkan dengan tidak ditemukannya kematian benih ikan kerapu di tambak. Hal ini menunjukkan bahwa kelulushidupan ikan kerapu di BBPBAP Jepara cukup baik.

Tahap pemeliharaan kerapu tikus setelah pendederan adalah tahap pembesaran, dimana tahap ini dilakukan selama $16-18$ bulan. Pada tahap ini BBPBAP melakukan penjarangan atau pengurangan padat tebar dari 200 ekor $/ \mathrm{m}^{2}$ menjadi 15 ekor $/ \mathrm{m}^{2}$. Pada tahap pembesaran dilakukan penjarangan atau pengurangan padat tebar dari $200 \mathrm{ekor} / \mathrm{m}^{2}$ menjadi 5 10 ekor $/ \mathrm{m}^{2}$ (Komarudin, 2005). Benih untuk pembesaran merupakan hasil dari pendederan yang memiliki berat antara $30-50$ gram/ekor dan telah 
mencapai panjang $10-12 \mathrm{~cm}$. Pada tambak pembesaran kerapu tikus di BBPBAP Jepara ukuran sekatnya adalah $441,5 \mathrm{~m}$, dengan ukuran mata jaring 0,5 inchi dengan padat tebar $15 \mathrm{ekor} / \mathrm{m}^{2}$.

Pemindahan ikan kerapu dari hapa pendederan ke hapa pembesaran di tambak BBPBAP Jepara dilakukan dengan mengambil ikan dengan serok, kemudian menampungnya pada bak penampungan (fiber glass). Setelah itu, dilakukan penghitungan dan pemeriksaan fisik ikan, hal ini bertujuan agar ikan yang sakit segera diketahui. Kegiatan pemindahan ini dilakukan pada pagi hari. Hal ini sesuai dengan pernyataan Dinas Perikanan dan Kelautan Propinsi Jawa Timur (2002) bahwa penebaran ikan dari hapa pendederan ke hapa pembesaran dilakukan pada pagi hari untuk menghindari fluktuasi suhu yang terlalu tinggi yang dapat mengakibatkan stres pada ikan.

Usaha BBPBAP Jepara untuk menjaga kelancaran sirkulasi air adalah dengan membersihkan jaring secara periodik yaitu pada saat dilakukan pengambilan contoh. Hal ini dilakukan mengingat masa pemeliharaan ikan kerapu tikus hingga mencapai ukuaran konsumsi membutuhkan waktu yang lama yaitu 16 - 18 bulan. Sedangkan untuk menjamin ketersediaan oksigen serta menjaga kualitas air, BBPBAP Jepara juga menggunakan kincir air yang dihidupkan pada malam hari hingga pagi hari. Kincir disediakan untuk menjamin ketersediaan oksigen dan membuang senyawa beracun, seperti amoniak dan hidrogen sulfida (Komarudin, 2005).

Laju pertumbuhan merupakan peningkatan dalam satuan panjang dan berat per unit waktu (Sunyoto, 1994). Data yang umum dipakai untuk mengetahui pertumbuhan adalah berat. Pada umumya pertumbuhan berat ikan berlainan dengan burung atau mamalia, dimana pertumbuhan pada ikan tidak berhenti setelah mencapai kematangan seksual. Cara untuk menghitung laju pertumbuhan harian (LPH) pada ikan kerapu yang dinyatakan dalam \% adalah sebagai berikut :

$$
\mathrm{LPH}=\frac{\mathrm{Bh}-\mathrm{Bo}}{\frac{\mathrm{Bh}+\mathrm{Bo}}{2} \times \mathrm{h}} \times 100 \%
$$

$$
\text { Keterangan: } \begin{aligned}
\mathrm{LPH} & =\text { laju pertumbuhan harian } \\
\mathrm{Bo}= & \text { berat ikan rata }- \text { rata awal } \\
& \text { pemeliharaan } \\
\mathrm{Bh}= & \text { berat rata }- \text { rata pada hari } \mathrm{ke}-\mathrm{h}
\end{aligned}
$$

Sumber: Sunyoto (1994)
Berdasarkan perhitungan LPH, kerapu tikus yang memiliki berat rata-rata awal 5,6 gr serta berat rata- rata 8,2 gr setelah dipelihara selama 14 hari diperoleh hasil LPH sebesar 2,69\%. Menurut Sunyoto (1994), besarnya LPH tergantung jenis dan ukuran ikan, misalnya untuk kerapu lumpur yang berukuran 50 - 100 gr mempunyai LPH sekitar $2-3 \%$, sedangkan untuk kerapu sunu berukuran 200 - 300 gr memiliki LPH sebesar 0,3 - 0,7 \%. Sunyoto (1994) menyatakan bahwa laju pertumbuhan kerapu tikus paling lambat diantara ikan kerapu jenis lainnya. Berdasarkan pernyataan di atas maka nilai laju pertumbuhan harian kerapu tikus di BBPBAP Jepara sudah cukup baik.

Pakan merupakan salah satu faktor penting dalam menunjang usaha budidaya. Pakan yang digunakan pada pembesaran kerapu tikus di BBPBAP Jepara adalah pakan ikan rucah (muniran, petek) yang dicacah sesuai dengan ukuran bukaan mulut ikan kerapu. Saat ini pakan yang digunakan oleh BBPBAP Jepara untuk budidaya kerapu tikus masih didominasi oleh ikan rucah. Komarudin (2005) menyatakan bahwa ikan rucah memiliki berbagai kelemahan diantaranya ketersediaannya tergantung musim, harga yang cenderung meningkat dan penyimpanan yang tidak tahan lama.

Perkiraan jumlah pakan ikan kerapu tikus di BBPBAP Jepara, dilakukan dengan penghitungan biomassa terlebih dahulu. Biomassa diperoleh dengan mengalikan jumlah ikan dengan berat rata-ratanya, setelah diketahui besarnya biomassa ikan kerapu tikus, kemudian nilai biomassa tersebut dikalikan dengan dosis pakan. Jumlah pakan yang diberikan di BBPBAP Jepara pada tahap pendederan adalah sebesar $20 \%$ dari biomassa yaitu berkisar 90 gram, sedangkan untuk pembesaran jumlah pakan yang diberikan sebanyak 10\%. Menurut Komarudin (2005), pada masa pendederan dosis pakan yang diberikan adalah $6-8 \%$ dari biomassa, sedangkan pada masa pembesaran dosis pakan adalah $3-5 \%$. Di sini terlihat ada perbedaan dosis pakan antara di tambak BBPBAP Jepara dengan pernyataan Komarudin. Hal ini disebabkan padat tebar pada tambak BBPBAP Jepara cukup tinggi, sehingga dibutuhkan jumlah pakan yang lebih banyak. Hal ini sesuai dengan pernyataan Direktorat Jenderal Perikanan Budidaya (2004) bahwa padat tebar yang tinggi tidak berpengaruh terhadap ikan peliharaan selama pengelolaan kualitas air dan jumlah pakan cukup.

Pemberian pakan kerapu di BBPBAP Jepara dilakukan sebanyak 2 kali sehari, yaitu pagi hari jam 07.00 dan sore hari jam 16.00. Hal ini karena pada 
waktu tersebut merupakan waktu paling efektif untuk pemberian pakan. Hal ini sesuai dengan pernyataan Tampubolon dan Mulyadi (1989) bahwa kerapu tikus mempunyai kebiasaan makan pada siang dan malam hari tetapi lebih aktif pada waktu fajar dan senja hari. Menurut Komarudin (2005), pemberian pakan ikan kerapu dilakukan sebanyak 2 kali, yaitu pagi hari jam 07.00 dan sore hari jam 17.00. Pemberian pakan ikan kerapu tergantung suhu dan salinitas, dimana apabila suhu naik nafsu makan akan meningkat, begitu pula jika salinitas naik maka nafsu makan pun naik. Bila kondisi ad libitum telah tercapai, pemberian pakan harus dihentikan untuk menghindari terbuangnya pakan, walaupun belum mencapai dosis yang telah ditentukan. Agar lebih efektif, pemberian pakan biasanya dipusatkan pada suatu tempat, dengan cara memberikan ketukan di satu sudut tambak, maka ikan akan terlatih untuk datang ke tempat pemberian pakan pada waktu pemberian pakan.

Pengelolaan pakan dalam bentuk ikan rucah di BBPBAP Jepara dilakukan dengan menyimpan ikan tersebut di dalam freezer untuk mencegah pembusukan lebih cepat. Batas penyimpanan ikan rucah di BBPBAP Jepara biasanya 3 - 4 hari. Sunyoto (1994) menyatakan bahwa batas maksimal penyimpanan ikan rucah selama 7 hari. Nafsu makan ikan kerapu berkurang apabila ikan rucah yang diberikan telah mengeluarkan bau yang tidak sedap. Hal ini disebabkan karena pada tubuh ikan terjadi denaturasi protein dan oksidasi asam lemak. Murniyati dan Sunarman (2002) menyatakan bahwa penyimpanan pada suhu rendah dapat mengakibatkan denaturasi protein sehingga terjadi penurunan kadar protein. Usaha pengelolaan pakan yang lain adalah dengan mencampurkan vitamin pada pakan. BBPBAP Jepara menambahkan Vitamin $C$ pada pakan kerapu tikus untuk meningkatkan daya tahan tubuh ikan, meningkatkan nafsu makan serta mengurangi stres pada ikan. Penambahan vitamin dapat meningkatkan kekebalan tubuh dan survival rate ikan (www.dkp.go.id., 2005).

Pengelolaan air di BBPBAP Jepara dilakukan dengan cara pergantian air dan pengontrolan kualitas air. Pergantian air pada tambak pembesaran kerapu di BBPBAP Jepara dilakukan pada pagi hari sebanyak $10-20 \%$ dari voume total. Selain untuk mempertahankan kesegaran air tambak pergantian air juga sebagai upaya pencegahan terhadap penyakit yang timbul. Menurut SEAFDEC (2001), pergantian air dilakukan dengan pemanfaatan pasang surut atau dengan menggunakan pompa yang dilakukan sebanyak $50 \%$ sebanyak 2 kali seminggu.
Suhu air tambak diukur setiap hari, yaitu pada pagi dan sore hari dengan manggunakan termometer. Pengukuran suhu di BBPBAP Jepara diperoleh hasil sebesar $28-29^{\circ} \mathrm{C}$. Menurut Supratno dan Kasnadi (2003), suhu optimal untuk budidaya ikan kerapu tikus adalah berkisar $27-32^{\circ} \mathrm{C}$, sehingga suhu di tambak BBPBAP Jepara tersebut layak bagi kehidupan kerapu tikus.

Hasil pengukuran salinitas di tambak pembesaran BBPBAP Jepara adalah 32 ppt. Menurut Supratno dan Kasnadi (2003), ikan kerapu merupakan hewan yang bersifat euryhaline, dengan toleransi salinitas sebesar 5 - 35 ppt. Berdasarkan pernyataan tersebut, salinitas air di tambak masih dapat ditoleransi bagi kehidupan ikan kerapu. Untuk mengantisipasi adanya kenaikan salinitas air tambak pada saat musim kemarau, usaha yang dilakukan adalah dengan mengubah salinitas air tambak yang dilakukan dengan pergantian air atau dengan penambahan air tawar.

Kandungan oksigen terlarut diukur dengan menggunakan alat DO meter Dari hasil pengukuran oksigen terlarut yang dilakukan pada tambak pembesaran ikan kerapu tikus di BBPBAP Jepara, diperoleh hasil pengukuran sebesar 3,35 ppm. Menurut Supratno dan Kasnadi (2003), kisaran oksigen terlarut untuk pemeliharaan ikan kerapu tikus adalah 3,5 - 5,4 ppm, dimana pengukuran dilakukan seminggu sekali. Berdasarkan pernyataan tersebut, maka kondisi ini masih aman bagi kehidupan ikan kerapu. Usaha BBPBAP Jepara untuk meningkatkan kelarutan oksigen pada tambak dilakukan dengan penambahan kincir air yang dihidupkan pada sore hari hingga pagi hari.

Pengukuran amoniak pada tambak pembesaran ikan kerapu tikus di BBPBAP Jepara dilakukan hanya sekali, dengan hasil sebesar 0,0025 mg/l. Menurut Supratno dan Kasnadi (2003), kisaran amoniak untuk pembesaran ikan kerapu tikus adalah sebesar 0,002 - 0,048 mg/l, dimana pengukuran amoniak dilakukan 2 minggu sekali. Berdasarkan pernyataan di atas, maka kadar tersebut masih layak bagi kehidupan ikan kerapu tikus.

Derajat keasaman air ditentukan oeh konsentrasi ion $\mathrm{H}$ yang digambarkan dengan angka 1 sampai 14 (Sunyoto, 1994). Pengukuran pH di BBPBAP Jepara dilakukan oleh pegawai dari laboratorium lingkungan, sebanyak 2 minggu sekali. Usaha yang dilakukan untuk menaikkan $\mathrm{pH}$ di tambak dilakukan dengan pengapuran sehingga $\mathrm{pH}$ layak untuk kelangsungan hidup ikan kerapu. Hal ini dilakukan karena $\mathrm{pH}$ di tambak hanya berkisar 6,5. Menurut Supratno dan Kasnadi (2003), kisaran pH 
yang optimal untuk budidaya kerapu di tambak adalah 7,6 - 8,9. Perubahan $\mathrm{pH}$ tersebut disebabkan adanya pengaruh dari tanah tambak maupun aktivitas organisme dalam tambak. Dengan demikian tanah tambak juga harus memiliki $\mathrm{pH}$ yang optimal.

Penyakit didefinisikan sebagai gangguan suatu fungsi atau struktur dari alat tubuh atau sebagian alat tubuh (Sunyoto, 1994). Penyakit muncul sebagai suatu proses interaksi antara inang, penyebab penyakit (pathogen) dan lingkungan.

Selama pelaksanaan Studi Kasus tidak ditemukan serangan penyakit terhadap ikan kerapu tikus yang dipelihara. Namun saat dilakukan sampling, ditemukan adanya parasit Caligus sp. Gejala klinis pada ikan yang terserang Caligus sp. di BBPBAP Jepara tidak nampak jelas dari luar, sehingga sulit untuk mengetahui adanya parasit tersebut. Namun hal ini dapat diketahui dengan mengamati respon ikan terhadap pakan, yaitu tidak munculnya sebagian kerapu tikus ke permukaan air seperti biasanya pada saat pemberian pakan. Berdasarkan pengamatan, jumlah kerapu tikus yang terserang parasit ini adalah 10 ekor. Subyakto dan Cahyaningsih (2003), menyatakan bahwa gejala klinis yang timbul akibat serangan Caligus sp. antara lain insang mengalami kerusakan sehingga berwarna pucat, terkelupasnya sisik ikan, serta nafsu makan menurun. Menurut Taslihan dkk, terdapat beberapa cara penanggulangan jenis parasit Caligus sp., yaitu perendaman dengan menggunakan air tawar $100 \%$ atau menggunakan hidrogen peroksida. Berdasarkan pernyataan di atas, usaha BBPBAP Jepara untuk menanggulangi parasit ini adalah dengan menggunakan air laut yang ditambahkan hidrogen peroksida $(60 \mathrm{ml})$ dan juga perendaman dengan air tawar $100 \%$. Hasilnya, parasit Caligus sp. terlepas dan terlihat transparan keabu-abuan.

Pencegahan merupakan upaya awal dalam pengendalian penyakit. Upaya pencegahan penyakit yang dilakukan di BBPBAP Jepara antara lain, menghindari kontak antara ikan dengan patogen, yaitu dengan melakukan kontrol lingkungan khususnya kualitas air, serta pemeriksaan kondisi fisik ikan pada saat dilakukan sampling. Selain itu usaha pancegahan lainnya adalah dengan pemberian pakan yang optimal, yaitu dengan panambahan vitamin $\mathrm{C}$ pada pakan. Pencegahan penyakit infektif dapat dilakukan dengan 4 cara yaitu, menghindari kontak antara ikan dengan patogen, menurunkan tingkat infeksi dengan memperkecil jumlah patogen dalam lingkungan, meningkatkan daya tahan ikan dengan pemberian pakan yang optimal (secara kuantitatif maupun kualitatif), serta imunisasi (Zonneveld, Huismann dan Boon, 1991).

Pada saat pelaksanaan Studi Kasus, ikan belum mencapai ukuran konsumsi, sehingga tidak dilakukan kegiatan panen. Menurut hasil wawancara, panen yang dilakukan di BBPBAP adalah dengan mengangkat jaring dan mengambil ikan dengan menggunakan seser, kemudian menampung ikan hasil panen dalam bak berisi air laut segar. Panen dilakukan sebagian karena tergantung permintaan pembeli baik ukuran maupun jumlahnya.

Menurut Supratno dan Kasnadi (2003) cara pemanenan ada 2 yaitu, panen sebagian dan panen keseluruhan. Panen sebagian adalah memanen sebagian ikan yang telah mancapai ukuran konsumsi. Sedangkan panen keseluruhan dilakukan dengan mengambil seluruh ikan yang terdapat di tambak. Pemanenan dilakukan dengan memasang jaring ukuran 8 21,5 m atau 8 4,5 m dengan mata jaring 25 $\mathrm{mm}$, dilakukan pada pagi atau sore hari. Panen dilakukan dengan menurunkan air 2 jam sebelum panen agar daging ikan tidak terlalu kaku, karena stres. Cara lain adalah dengan memasang jaring di bawah tempat pakan untuk memanen sedikit demi sedikit. Hasil panen disimpan dalam jaring dengan kepadatan 20 ekor $/ \mathrm{m}^{2}$.

Pengangkutan di BBPBAP Jepara, dilakukan melalui darat dengan menggunakan bak yang diisi air yang diberi aerasi dengan kepadatan yang disesuaikan dengan ukuran ikan hasil panen.

Menurut SEAFDEC (2001), cara pengepakan dan transportasi ikan kerapu adalah sebagai berikut:

Ikan diangkut melalui jalur darat dengan cara:

a. Menampung ikan hasil panen dalam bak yang diaerasi.

b. Menurunkan suhu air hingga $2^{\circ} \mathrm{C}\left(2-3^{\circ} \mathrm{C} / \mathrm{jam}\right)$ dengan merendam es yang dibungkus plastik atau pompa pendingin.

c. Memasukkan ikan $3-5$ ekor ke dalam kantong plastik lapis dua, berat ikan $\quad 2-3 \mathrm{~kg} / \mathrm{kantong}$.

Pengangkutan ikan melalui udara (8 jam), dilakukan dengan cara:

a. Memasukkan ikan dalam kantong plastik, dengan air yang cukup agar ikan terendam.

b. Perbandingan oksigen dengan air $3: 1$.

c. Kantong plastik diikat dengan karet.

d. Kemudian kantong plastik dipak dengan styrofoam.

e. Menambahkan es yang dibungkus plastik, lalu menyelipkan diantara kantong plastik dalam styrofoam. 
Pasar sangat penting bagi kelangsungan produksi. Untuk ikan kerapu tujuan pasar ada 2, yaitu pasar dalam negeri dan luar negeri. Sistem pemasaran ikan kerapu tikus di BBPBAP Jepara dilakukan menurut pesanan, dalam pengertian pemanenan dilakukan apabila ada permintaan dari konsumen. Para pengepul dan eksportir datang ke lokasi untuk melihat terlebih dahulu dan melakukan negosiasi harga. Setelah terjadi kesepakatan harga maka ditentukan waktu pemanenannya.

Menurut Supratno dan Kasnadi (2003), tujuan pasar luar negeri untuk ikan kerapu adalah Hongkong, Taiwan, dan Jepang. Sedangkan pasar dalam negeri biasanya kota besar seperti, Jakarta, Semarang, Surabaya, dan kota-kota lainnya.

Menurut Subyakto dan Cahyaningsih (2003), tujuan analisis usaha antara lain adalah untuk memperkirakan besarnya modal yang diperlukan, serta untuk memperkirakan keuntungan yang akan diperoleh.

Perhitungan analisis usaha di BBPBAP Jepara untuk satu siklus pemeliharaan adalah mulai tahap pendederan hingga mencapai ukuran konsumsi (300 - 400 gram). Dari hasil perhitungan tersebut dapat dijelaskan bahwa dengan modal awal sebesar Rp. 113.672.000,00 dapat diperoleh keuntungan sebesar Rp. 241.753.000,00 dengan rata-rata keuntungan per bulan adalah sebesar Rp. 13.430.722,00. Adapun untuk Benefit /Cost Ratio (B/C Ratio) usaha pembesaran kerapu tikus adalah sebesar 3,13. Hal ini berarti bahwa dengan modal sebesar Rp. 1,00 dapat diperoleh hasil Rp. 3,13. Untuk Break Event Point (BEP) volume produksi adalah sebesar 645,55 ekor 645 ekor. Hal ini berarti bahwa dengan menghasilkan 650 ekor dan menjual dengan harga per ekor Rp. 175.000,00 sudah dapat mengembalikan modal awal atau impas. Sedangkan untuk BEP harga produksi adalah sebesar Rp. 55.968,00. Hal ini berarti bahwa dengan menjual ikan kerapu tikus dengan harga Rp. 55.968,00 sebanyak 1850 ekor sudah dapat mengembalikan modal awal atau impas.

Berdasarkan hasil B/C Ratio sebesar 3,13; BEP volume produksi sebesar 650 ekor; serta BEP harga produksi sebesar Rp. 55.968,00; keuntungan per bulan sebesar Rp. 13.430.722,00 maka usaha pembesaran ikan kerapu tikus dapat dijadikan peluang usaha yang sangat menjanjikan.

Hambatan yang dihadapi adalah terbatasnya pengadaan sendiri ikan rucah sebagai pakan baik kualitas maupun kuantitasnya. Hal ini disebabkan ikan rucah yang digunakan tidak dapat diperoleh sewaktuwaktu. Ketersediaan ikan rucah dipengaruhi oleh musim dan jenisnya tidak seragam, sehingga kandungan gizinya tidak dapat diketahui secara pasti.

Hambatan lainnya adalah konstruksi outlet pada tambak pembesaran ikan kerapu tikus di BBPBAP Jepara lebih tinggi daripada tambak, sehingga menyebabkan kesulitan dalam proses pembuangan air dan memerlukan tambahan tenaga pompa untuk membantu dalam proses pembuangan air.

Berdasarkan hasil B/C Ratio sebesar 3,13; BEP volume produksi sebesar 650 ekor; BEP harga produksi sebesar Rp. 55.968,00; serta keuntungan per bulan sebesar Rp. 13.430.722,00 maka usaha pembesaran ikan kerapu tikus memiliki potensi yang bagus untuk dikembangkan di masa yang akan datang mengingat peluang pasar yang masih terbuka lebar baik pasar dalam maupun luar negeri. Selain itu potensi lahan yang cukup luas, dimana ikan kerapu ini tidak harus dipelihara di tambak baru.

\section{Kesimpulan}

Manajemen pembesaran ikan kerapu tikus (Cromileptes altivelis) di BBPBAP Jepara dilakukan dengan pemindahan tempat dari hapa pendederan ke tambak pembesaran, serta panjarangan (pengurangan padat tebar) yaitu dari 200 ekor $/ \mathrm{m}^{2}$ pada tahap pendederan menjadi 15 ekor $/ \mathrm{m}^{2}$ pada tahap pembesaran. Parameter kualitas air pada tambak pembesaran kerapu tikus sudah dalam keadaan optimal, dimana salinitas sebesar $31-32$ ppm, suhu berkisar $27-28^{\circ} \mathrm{C}$, oksigen terlarut 3,35 ppm. Pakan yang diberikan di BBPBAP Jepara adalah ikan rucah (muniran dan petek), yang diberikan sebanyak 2 kali yaitu pada pagi hari jam 07.00 dan sore hari jam 16.00. Pada tambak pembesaran kerapu tikus tidak ditemukan serangan penyakit, hanya ditemukan sejenis parasit, yaitu Caligus sp. pada waktu dilakukan sampling. Dalam pemeliharaan ikan kerapu tikus di tambak, sebaiknya pakan yang diberikan dikombinasi dengan pakan buatan, mengingat ketersediaan pakan ikan rucah terbatas tergantung musim. Konstruksi outlet sebaiknya lebih rendah dari konstruksi tambak sehingga pembuangan air tambak tidak memerlukan pompa yang terlalu banyak.

\section{Daftar Pustaka}

Buwono, I. D. 1993. Tambak Udang Windu Sistem Pengelolaan Berpola Intensif. Kanisius: Yogyakarta.

Dinas Perikanan dan Kelautan Propinsi Jawa Timur. 2002. Panduan Pengelolaan Kesehatan Ikan. Dinas Perikanan dan Kelautan Propinsi Jawa Timur. Surabaya. 
Direktorat Jenderal Perikanan Budidaya. 2004. Petunjuk Teknis Budidaya Laut Ikan Kerapu /seri 11/ BDL/ 04. Direktorat Jenderal Perikanan Budidaya. Jakarta.

Komarudin, U. 2005. Budidaya Ikan Kerapu di Tambak. Makalah Kuliah Lapang Mahasiswa UNAIR, 8 Mei 2004 di BBPBAP Jepara. Balai Besar Pengembangan Budidaya Air Payau Jepara. 25 hal.

Murniyati dan Sunarman. 2002. Pendinginan, Pembekuan dan Pengawetan Ikan. Kanisius. Yogyakarta.

South East Asian Fisheries Development Center (SEAFDEC). 2001. Pembudidayaan dan Manajemen Kesehatan Ikan Kerapu. Direktorat Jenderal Perikanan. Jakarta. 95 hal.

Subyakto, S dan S. Cahyaningsih. 2003. Pembenihan Kerapu Skala Rumah Tangga. Agromedia Pustaka. Jakarta. 62 hal.
Supratno, K. P. T. dan Kasnadi. 2003. Peluang Usaha Budidaya dengan Pembesaran Kerapu di Tambak Melalui Sistem Modular. Makalah pada Pelatihan Budidaya Udang Windu Sistem Tertutup bagi Petani Tambak Tegal dan Jepara, Jawa Tengah. Balai Besar Pengembangan Budidaya Air Payau Jepara. 17 hal.

Suryabrata, S. 1993. Metode Penelitian. CV. Rajawali. Jakarta. 115 hal.

Suyanto., S. Rachmatun dan A. Mujiman. 2004. Budidaya Udang Windu. Penebar Swadaya . Jakarta. 213 hal.

Tampubolon, G. H. dan E. Mulyadi.1989. Sinopsis Ikan Kerapu di Perairan Indonesia. Balai Penelitian dan Pengembangan Perikanan. Semarang.

www.dkp.go.id. 2005. Produksi Benih Kerapu Macan. http://www.dkp.go.id. 2 hal.

www.warintek.bantul.or.id. 2006. Budidaya Udang Windu. http://www.warintek.bantul.or.id/ konstruksi/tambak/budidaya.htm

Zonneveld, N., E. A. Huismann dan J. H. Boon. 1991. Prinsip- prinsip Budidaya Ikan. PT Gramedia Pustaka Utama . Jakarta. 318 hal. 